cataloging rules.-Helen B. Uhrich, Yale Divinity School Library.

\section{Architecture and Libraries}

Forms and Functions of Twentieth-Century Architecture. Talbot F. Hamlin, editor. (4 vols.). New York: Columbia University Press, I952. \$75.00.

Most librarians facing a library building project are likely to be quite deficient in their knowledge of architecture. To dispel their ignorance in this vital area, they could perhaps do no better than go into seclusion for about four weeks, equipped with Hamlin's 22-pound monumental compendium of architectural information. After having absorbed the content of the 3446 pages, including 3745 illustrations, which cover a vast amount of theoretical and practical knowledge, they will be much better prepared to understand their architects and to confer with them intelligently and constructively. Most of all, they will have rid themselves of the false notion that a librarian's idea of a library building must necessarily be in conflict with an architect's idea of a library building.

This is not the place for presenting a comprehensive critical review of the 4 -volume work from the professional architectural point of view. It should suffice to present a brief summary of the chief points of criticism and praise and point to specific features of interest to librarians. The work was edited by the former Avery librarian of Columbia University's School of Architecture, who was also a professor of architectural history and theory; it took five years to write and edit the publication. Volumes $\mathrm{I}$ and 2, presenting a survey of the elements of building and structure and the principles of architectural composition, were written almost completely by the editor; volumes 3 and 4 , dealing largely with individual building types or the social function of architecture, were written by $5 \mathrm{I}$ specialists, most of whom were practicing architects.

The work is eminently readable throughout, is attractively printed, and the illustrations have, for the most part, been carefully selected to clarify the text rather than merely to embellish it. The philosophy underlying the work is that contemporary architecture has grown out of the traditions of the past, that the basis of architecture lies in the social needs of man. The work has been criticized, on the other hand, for devoting too much space to history of architecture and history of architectural theory, for being weak on its formulation of the philosophy of contemporary architectural design, for its distinctly American orientation despite its many illustrations drawn from international architecture, and for its failure to provide much guidance to those whose job it is to make architecture progress. None of these criticisms, however, detract seriously from the value of the work as a comprehensive survey of virtually all aspects that are relevant to 2oth century building problems.

Libraries as a building type are treated in a special 40-page chapter, written by Alfred $M$. Githens, an architect of much experience in library building design, whose work includes the Baltimore and Brooklyn public libraries, the Joint University Libraries, and most recently the new modular library of the University of Georgia. Almost one-third of the chapter is devoted to library building history of an excessively antiquarian character; the rest of the chapter deals succinctly with standards of library design, elements of library buildings, types of library buildings, factors to be considered in planning, and future trends. Mr. Githens expresses the view that the alleged traditional animosity between architect and librarian has been gradually disappearing with the current trend toward functionalism. He clearly enumerates the essentials in library design and correctly emphasizes that library building plans must be based on actual requirements rather than precedent.

At times, Mr. Githens fails to make a sufficiently clear distinction between what is current practice and what might be regarded as the most desirable practice. For instance, when he states ( $\mathrm{I}$ ) that "in a large public library the newspaper room is generally segregated and perhaps has its own outside entrance," he seems to imply approval of this segregation whereas many public librarians would not consider such segregation necessarily desirable; or (2) his statement that "except in very large libraries the desk or desks should be near the public entrance, with a clear view of it," may be taken to imply that such placement is recommended despite the fact that he recognizes that "many librarians believe that a desk should not face the entrance or be made conspicuous, lest the 
supervision be too evident." Mr. Githens' failure to distinguish clearly between current and desirable practice is evident in the following additional illustrations: (3) $\mathrm{He}$ states that "all available walls should be lined with books." (4) $\mathrm{He}$ asserts that "daylight is preferred in a library." All of these recommendations are debatable, and whatever happens to be the most frequent current practice may actually be the least desirable practice.

Some readers may feel that Mr. Githens' treatment of library buildings trends is perhaps a little too noncommittal compared to the way some other chapters are handled. There is quite a contrast between $\mathrm{Mr}$. Githens' rather neutral account of certain current trends in library building design and such emotionally charged condemnations or endorsements as the following taken from other chapters. With reference to department store design: "It is unfortunate that we have borrowed, as an environment for this comparatively recent retail process, the academic architectural styles" (Kenneth C. Welch); or with reference to bridges and highway architecture: "We all must move with the spirit of our times, and to an architect the only genuinely satisfying work is that which expresses the current mood; even those men who are regarded by the radical fringe as hopeless conservatives do work which 25 years ago would have been considered as extraordinarily advanced even by the radical fringe of that day. Fortunately the modern idiom with its emphasis on clean lines, on structure, and on the elimination of ornament is almost ideal as a treatment for engineering works" (Aymar Embury II).

Libraries receive additional attention in the chapters on college and universities and on daytime schools. Many observations applicable to libraries can also be found in the chapters on office building, factory buildings, hotels, department stores, acoustics, mechanical equipment, non-bearing walls, columns and piers, elements of the modern interior, color in architecture, and, last but not least, the chapter on the process of architectural planning, which emphasizes the importance of a program statement listing the requirements and purposes of any building to be designed.

The set can be highly recommended as a reference and working tool for all academic libraries. From the point of view of reference librarians, the usefulness of the publication has been greatly enhanced by the inclusion of 2 detailed indexes covering 102 pages, one arranged by subjects and one by architectural works. In addition, each chapter contains carefully selected bibliographies.Robert H. Muller, Southern Illinois University Libraries.

\section{California Librarians}

The California Librarian Education Survey, a report to President Robert G. Sproul, University of California. By Robert D. Leigh. New York, Columbia University, 1952. I IO p.

A California librarian would find it difficult indeed to take a detached view of a report which goes to the heart of the vital problem of the training and recruitment of librarians in California. To Dr. Robert D. Leigh was assigned the task of conducting a survey "to determine if there is need for an additional school of librarianship in California, and if so, whether 'that need may be met best by establishing such a school on the University's Los Angeles campus.'" The assignment was made on the basis of representations made to the Regents of the University that not enough librarians are graduated from the existing schools of librarianship at the University of California's Berkeley campus and the University of Southern California to meet the needs of a state which has doubled its population in ten years.

The resulting report not only summarizes Dr. Leigh's findings and recommendations with regard to an additional library school under the auspices of the University of California, but also includes a number of thoughtful and provocative suggestions for the development of librarian training in the state, which are concomitant conclusions gathered from the facts assembled by the survey.

Dr. Leigh has assessed the assumptions underlying the request for the survey and has produced the following conclusions:

(x) "that a scarcity of librarians for professional positions actually exists in the state and is of a size to call for an extension of training facilities;

(2) "that the growth of population in California will entail a growth of library service, but not so much an increase in pro- 